\title{
SPECIES COMPOSITION AND SIMILARITIES AMONG ANURAN ASSEMBLAGES OF FOREST SITES IN SOUTHEASTERN BRAZIL
}

\author{
Jaime Bertoluci ${ }^{1 *}$; Ricardo Augusto Brassaloti²; José Wagner Ribeiro Júnior²; Vívian Maria \\ de Faria Nasser Vilela²; Henrique Oliveira Sawakuchi² \\ ${ }^{1}$ USP/ESALQ - Depto. de Ciências Biológicas, C.P. 09 - 13418-900 - Piracicaba, SP - Brasil. \\ ${ }^{2}$ USP/ESALQ - Graduando em Ciências Biológicas. \\ *Corresponding author < bertoluc@esalq.usp.br>
}

\begin{abstract}
Neotropical forests show high anuran species richness, but some Brazilian forest formations, like cerradão, semideciduous forests and restingas, remain poorly known. The composition of anuran species were determined for four forest sites belonging to different biomes in southeastern Brazil, based on two complementary techniques (visual encounter survey and survey on breeding sites), both applied simultaneously. A total of 60 anuran species belonging to eight families was recorded. Species richness and levels of endemism were higher in the Atlantic rainforest site. Sites located in the Cerrado domain were more alike than those located in the Atlantic Forest Domain. Similarity in anuran species composition was negatively correlated to the geographical distance among sites, which explains part of similarities in species composition. Factors affecting these occurrence patterns are discussed. One species (if its identity is confirmed) is considered Data Deficient by IUCN (The World Conservation Union), though it is not included in the Brazilian list of threatened amphibians. The presence of certain species with special habitats and microclimate requirements (bioindicators) suggests well-preserved ecosystems.
\end{abstract}

Key words: anurans, species richness, species composition, conservation

\section{COMPOSIÇÃO DE ESPÉCIES E SIMILARIDADES ENTRE TAXOCENOSES DE ANUROS DE ÁREAS FLORESTAIS DO SUDESTE DO BRASIL}

\begin{abstract}
RESUMO: As florestas neotropicais apresentam altas riquezas de espécies de anuros, mas algumas formações florestais brasileiras, como o cerradão, as florestas semidecíduas e as restingas, permanecem pouco conhecidas. A composição de espécies de anuros de quatro áreas florestais pertencentes a diferentes biomas do sudeste do Brasil foi determinada com base em duas técnicas complementares (procura visual e investigação nos sítios reprodutivos), aplicadas de forma simultânea. Registramos um total de 60 espécies de anuros, incluídas em oito famílias. A riqueza de espécies e o nível de endemismo foram maiores na área coberta por floresta pluvial atlântica. As áreas localizadas no domínio do Cerrado foram mais similares entre si do que as áreas localizadas no domínio da Mata Atlântica. Os índices de similaridade mostraram-se negativamente relacionados com a distância geográfica entre as áreas, explicando parte das similaridades observadas. Os fatores que influenciam os padrões de ocorrência são discutidos. Uma das espécies (caso sua identidade seja confirmada) é considerada como Deficiente em Dados pela IUCN (The World Conservation Union), mas não está incluída na lista da fauna brasileira ameaçada de extinção. A presença de certas espécies com requisitos especiais de hábitat e microclima (bioindicadores) sugerem que os ecossistemas estão bem-preservados.

Palavras-chave: anfíbios, riqueza de espécies, ambientes de floresta, biodiversidade, conservação
\end{abstract}

\section{INTRODUCTION}

Despite its extreme diversity (Whitmore, 1990), anuran fauna of Brazilian forests is still poorly known. In recent decades, Brazilian forests were cleared for cattle farming and sugarcane, coffee and cocoa plantations, and less than $9 \%$ of the original Atlantic coast forest remains (Myers, 1986; Fearnside,
1990; 1996). This scenario of increasing habitat loss and degradation is associated to anuran declines and local extinctions (Heyer et al., 1988; 1990; Weygoldt, 1989; Haddad \& Sazima, 1992; Bertoluci \& Heyer, 1995; Bertoluci et al., 2005; Eterovick et al., 2005). Status of all Brazilian anurans was updated by the Global Amphibian Assessment workshop (GAA) (IUCN, Conservation International \& NatureServe, 2006). 
In Brazil, studies dealing with anuran communities of forest environments were concentrated in Amazonia (Crump, 1971; Hero, 1990; Gascon, 1991), in semideciduous forests of southeastern and southern regions (e.g. Haddad \& Sazima, 1992; Rossa-Feres \& Jim, 1994; Bernarde \& Kokubum, 1999; Toledo et al., 2003; Ribeiro et al., 2005; Bernarde \& Anjos, 1999; Machado et al., 1999; Bernarde \& Machado, 2001), and in the Atlantic rainforest (Heyer et al., 1990; Guix et al., 1994; Bertoluci, 1998; Bertoluci \& Rodrigues, 2002a; 2002b). The anuran fauna of other Brazilian forest formations like "cerradão" (the forest physiognomy of Cerrado) and the Restinga, however, remains virtually unknown. Pombal Jr. \& Gordo (2004) provided a list of anurans from the Estação Ecológica Juréia-Itatins (Rio Verde) that includes species of both Restinga and Atlantic rainforest habitats, and Narvaes (1993) developed a year-round study on anurans from Estação Ecológica Juréia-Itatins (Guarauzinho).

Species inventories and long-term monitoring of both population and community levels are essential to assess the conservation status of Brazilian anurans and to delineate actions for their conservation. Only continuous and long-term studies are able to separate human impacts from natural population fluctuations (Pechman et al., 1991).

The main goals of the present study included the determination of the species composition of anuran assemblages of four forest sites in different biomes in the state of São Paulo based on two complementary techniques applied simultaneously to the sites; the evaluation of the levels of similarity among the assemblages; the comparisons of these levels of similarity with the similarities among the same areas based on tree species composition; and the comparison of the composition of the assemblages with those of other Brazilian anuran communities.

\section{MATERIAL AND METHODS}

\section{Study Sites}

From September 2005 to August 2006, anuran species inventories were conducted in the following preservation reserves of the State of São Paulo, southeastern Brazil:

\section{Assis Ecological Station (Estação Ecológica de} Assis; EEA). With an area of 1,312.28 ha, EEA is located in the municipality of Assis $\left(22^{\circ} 33^{\prime}-22^{\circ} 36^{\prime} \mathrm{S}\right.$, $50^{\circ} 23^{\prime}-50^{\circ} 22^{\prime} \mathrm{W}$ ), at altitudes varying from 520 to $590 \mathrm{~m}$ above sea level. The climate is of the Cwa type of Köppen's classification, megathermic, tropical with a dry season in winter and rains concentrate in summer; mean annual temperature is $22.4^{\circ} \mathrm{C}$ and mean rainfall is $1255 \mathrm{~mm}$. The vegetation in EEA is of the
Cerrado latu sensu type, called “cerradão”, with a continuous canopy $15 \mathrm{~m}$ high and absence of grasses. This site lies in the Cerrado-Caatinga-Chaco Domain (mixed savanna and open forest formation) as described by Duellman (1999) based on the morphoclimatic domains of Ab’Saber (1977).

Caetetus Ecological Station (Estação Ecológica de Caetetus; EEC). This reserve belongs to the munici-

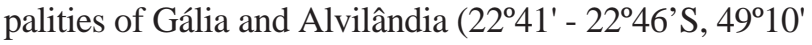
- 49 ${ }^{\circ} 16^{\prime} \mathrm{W}$ ) and has an area of 2,178.84 ha, inside the Médio Paranapanema river basin. The local climate is Cwa (Köppen's classification), mesothermic, subtropical, with dry winter; mean annual temperature is $21.4^{\circ} \mathrm{C}$ and mean annual raifall is $1313 \mathrm{~mm}$. The primary vegetation consists of a Semideciduous Seasonal Forest associated to the Planalto Ocidental do Estado de São Paulo. The altitude varies from 520 to $680 \mathrm{~m}$. This forest has some extremely well-preserved portions, housing many threatened plant and animal species (Tabanez et al., 2005), and also lies in the Cerrado-Caatinga-Chaco Domain.

Carlos Botelho State Park (Parque Estadual Carlos Botelho; PECB). Located in the southern part of the São Paulo state, in the municipalities of São Miguel Arcanjo, Capão Bonito and Sete Barras

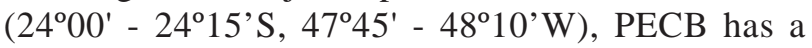
total area of $37,793.63$ ha, in altitudes varying from 30 to $1003 \mathrm{~m}$ (Domingues \& Silva, 1988). The present study was carried out in an area at about 500 $\mathrm{m}$, inside the Núcleo Sete Barras. The climate is Cfa (Köppen's classification), mesothermic, subtropical, wet and hot, without a dry season; mean annual temperature is $21.8^{\circ} \mathrm{C}$ and mean annual rainfall is 1582 $\mathrm{mm}$. This site is included in the Brazilian Highlands (coastal ranges and interior highlands), which belongs to the Atlantic Forest Domain (Ab'Saber, 1977; Duellman, 1999).

Ilha do Cardoso State Park (Parque Estadual da Ilha do Cardoso; PEIC). Situated in the southern coast of the state of São Paulo, in the municipality of Cananéia ( $\left.25^{\circ} 03^{\prime}-25^{\circ} 18^{\prime} \mathrm{S}, 47^{\circ} 53^{\prime}-48^{\circ} 05^{\prime} \mathrm{W}\right)$, this island has an area of 22,500 ha. The climate is Af (Köppen's classification), megathermic, tropical, without a dry season; mean annual temperature is $22.4^{\circ} \mathrm{C}$ and mean annual raifall is $2261 \mathrm{~mm}$. Relief is predominantly mountainous, with altitudes up to $800 \mathrm{~m}$. Distinct plant formations occur associated to diferent substrate characteristics: montane fields in shallow soils and rocky outcrops in mountain tops, Atlantic rainforest in sharp declivities, sand dune vegetation, Restinga forest in the coastal plain, and mangroves. The study was conducted in areas covered by Restinga forest at an altitude of 10 
m. This site is included in the Atlantic Coastal Forest, which also belongs to the Atlantic Forest Domain (Ab’Saber, 1977; Duellman, 1999).

Each site has a 10 ha permanent plot, consisting of a 320 m-sided square subdivided into 256 subplots (20 m-sided squares). Species inventories at the four sites were carried out inside the permanent plot, in a variable number of selected aquatic breeding sites (swamps, temporary pools, ponds, streams, and lake margins), and in trails and roads that give access to these sites and to the plots.

\section{Methods}

Each site was visited by two reasearchers every month for two days and two nights. Inside the permanent plot frogs were searched actively in the microhabitats commonly used by them, like leaf litter, underneath fallen logs, and in rock crevices. This visual encounter survey technique (Crump \& Scott, 1994) was applied by day along a 5,000 m transect (about 2,500 $\mathrm{m}$ at the PECB site due to its highly irregular relief) on the lines separating subplots. The monthly sampling effort was 20 hours/person and the total effort at each site was 240 hours/person. Each individual frog was captured and photographed, and had its snout-to-vent length (SVL) measured with a caliper to the nearest $0.5 \mathrm{~mm}$. All specimens but one voucher to each species were released after measurement.

At each site, the inventory was complemented by surveys in previously selected aquatic breeding sites (four in PECB and PEIC, five in EEA, and 10 in EEC). In these aquatic sites the number of calling males was recorded for each active species from $19 \mathrm{~h} 00$ to midnight. The list was completed by species that called during the day or outside the monitored sites.

At least one specimen by species was collected under IBAMA license $n^{\circ} 430 / 05$, killed by asphyxy in an atmosphere of $\mathrm{CO}_{2}$, fixed in formalin $10 \%$ and preserved in alcohol 70\% (Heyer et al., 1994).

\section{Data Analysis}

Alpha diversity was used here as a synonym of species richness (Primack, 1998). Hence, alpha diversity of each site was the number of species found there. In order to compare large areas gamma diversity was calculated for each pair of sites belonging to different domains (sites EEA+EEC, Cerrado-Caatinga-Chaco Domain; PECB+PEIC, Atlantic Forest Domain) as the number of species recorded at the two sites minus the number of species shared by the sites. Beta diversity (variability of species composition along a geographical or environmental gradient; Primack, 1998) was calculated as gamma diversity divided by mean alpha diversity.

To estimate the similarity between the pairs of sites in terms of anuran species composition, two indexes of similarity were used, both varying from zero (no similarity between both sites) to 1 (species composition identical in both sites): i) the Jaccard index of similarity, given by $J=N s / N_{A}+N_{B}-N s$, where $N s$ is the number of species shared by sites $A$ and $\mathrm{B}, N_{\mathrm{A}}$ is the number of species in site $\mathrm{A}$ and $N_{B}$ is the number of species in site $B$ (Zar, 1999), and ii) the Coefficient of Geographical Resemblance, defined by Duellman (1990) as CGR $=2 \mathrm{Ns} / \mathrm{N}_{\mathrm{A}}+$ $N_{B}$ (symbols as above). This index is identical to the index of Sorensen (Wolda, 1981), which duplicates the number of shared species, increasing similarity values. Jaccard's index was calculated in order to compare it with values obtained by Rodrigues (2003) based on tree species composition for the same sites.

A cluster analysis of the sites using CGR values was then performed, using the WPGMA linkage method (Sneath \& Sokal, 1973) because of the different number of species at each site (Dixo \& Verdade, 2006).

These four study sites were compared with other ten Brazilian sites (Figure 1) in terms of anuran species composition by means of cluster analy-

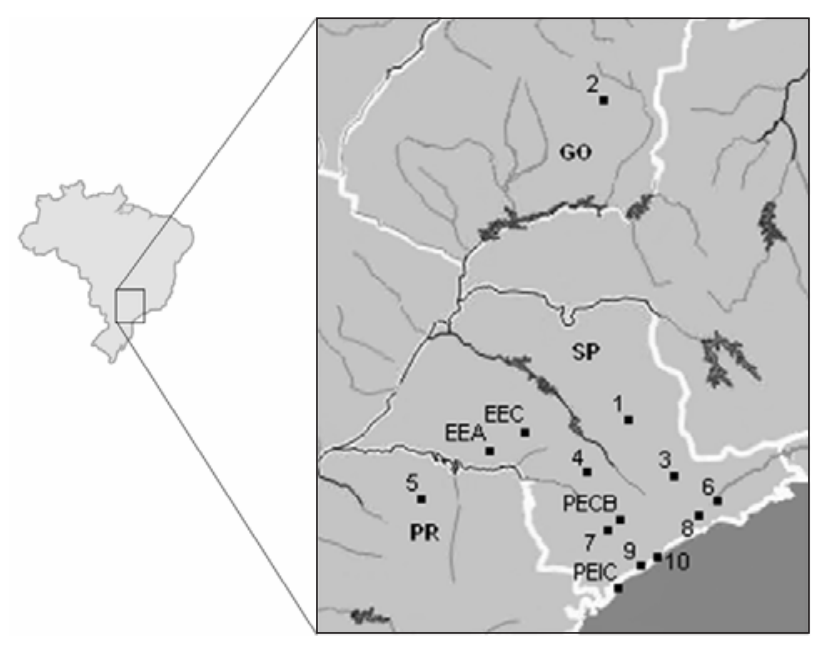

Figure 1 - Location of the study sites and ten other Brazilian sites used in comparisons of anuran species composition. Legend: EEA, Estação Ecológica de Assis; EEC, Estação Ecológica de Caetetus; PECB, Parque Estadual de Carlos Botelho; PEIC, Parque Estadual da Ilha do Cardoso; 1. Estação Ecológica de Itirapina (Brasileiro et al., 2005); 2. Floresta Nacional de Silvânia (Bastos et al., 2003); 3. Serra do Japi (Haddad \& Sazima, 1992; Ribeiro et al., 2005); 4. Botucatu (Rossa-Feres \& Jim, 1994); 5. Parque Estadual Mata dos Godoy, Londrina (Bernarde \& Anjos, 1999); 6. Estação Biológica de Boracéia (Heyer et al., 1990; Bertoluci et al., 2005); 7. Parque Estadual de Intervales (Bertoluci, 1998); 8. Reserva Biológica de Paranapiacaba (Vanessa K. Verdade, pers. commun.); 9. Estação Biológica Juréia-Itatins, Rio Verde (Pombal Jr. \& Gordo, 2004); 10. Estação Biológica Juréia-Itatins, Guarauzinho (Narvaes, 1993). 
sis using CGR and the WPGMA linkage method. To avoid taxonomic problems, this analysis excluded all undetermined species cited in the original papers as sp., gr. (species group) and aff. (affinis), but included in the analysis species cited as cf. (confer).

The relationship between the geographical distance (in $\mathrm{km}$ ) between pairs of sites and their respective indexes of similarity (CGR) was estimated by two independent simple regression analyses: the first included only the four sites of this study; in the second, the ten selected sites mentioned above were added. Regression analyses were performed with the software BioEstat 3.0 (Ayres et al., 2003). Cluster analyses were performed with the software FITOPAC (Shepherd, 1996).

\section{RESULTS AND DISCUSSION}

Throughout the four study sites a total of 60 anuran species belonging to the families Brachycephalidae (2 species), Bufonidae (6), Cycloramphidae (3), Hylidae (28), Hylodidae (2), Leiuperidae (6), Leptodactylidae (8), and Microhylidae (5) was recorded (Table 1). The phylogenetic arrangement recently proposed by Frost et al. (2006) was adopted here, except for species of the subfamily Hylodinae (included in Cycloramphidae) which was elevated to the level of family (Hylodidae), and for species of Physalaemus, currently of the newly proposed family Leiuperidae (Grant et al., 2006). Anuran fauna of all sites is largely dominated by family Hylidae. This pattern is common in South American areas belonging to different biomes (Heyer et al., 1990; Rossa-Feres \& Jim, 1994; Bertoluci \& Rodrigues, 2002b; Pombal Jr. \& Gordo, 2004; Brasileiro et al., 2005). In fact, this family of specialized arboreal anurans constitutes $25 \%$ of the South American anuran fauna (Duellman, 1999).
The most species-rich site was PECB (28 species), followed by EEC (24), EEA (19), and PEIC (16) (Table 1). These numbers must be considered partial, since no inventory techniques were applied able to detect rare species. For example, Guix et al. (1994) found 40 species in PECB area; their study, however, was developed along an altitudinal transect (22 to $1003 \mathrm{~m}$ ). This richness is similar to that recorded in Parque Estadual Intervales (47), an Atlantic rainforest reserve located in the same region (Bertoluci \& Rodrigues, 2002b).

Nineteen species were found only in PECB and nine species were collected only in PEIC. In EEA and EEC only five exclusive species each were found. Only the hylid Hypsiboas faber was recorded in the four sites. Proportion of shared species was higher in EEC (19 species, 79.2\%), followed by EEA (14, 73.7\%), PEIC (7, 44\%), and PECB (9 species, 32.1\%). The similarity in anuran species composition between each pair of sites are shown in Table 2. The most similar sites were EEC and EEA (CGR $=0.6512 ; 14$ shared species in a total of 29 species), followed by the pair PEIC and PECB (CGR = 0.2927; 6 in 35). The most different sites were EEA and PEIC (CGR $=0.0606$; 1 in 32) followed by the pair EEA and PECB (CGR = $0.0870 ; 2$ in 44). These values contrast to similarities (Jaccard) among the same sites based on tree species (Rodrigues, 2003) (Table 2). The most similar sites in terms of anuran composition (EEA-EEC, $J=0.4828$ ) were very dissimilar $(J=0.0535)$ in tree species composition. Other factors can explain these similarities, as can be seen below.

Figure 2 shows the dendrogram obtained for the four sites. Geographical distance among sites has no influence on tree species similarities ( $\mathrm{f}=0.8599$, $\mathrm{R}^{2}=-2.88 \%, P=0.5911$ ), but geographical distance explains at least part of the greater similarities in anuran species composition occurring between pairs of

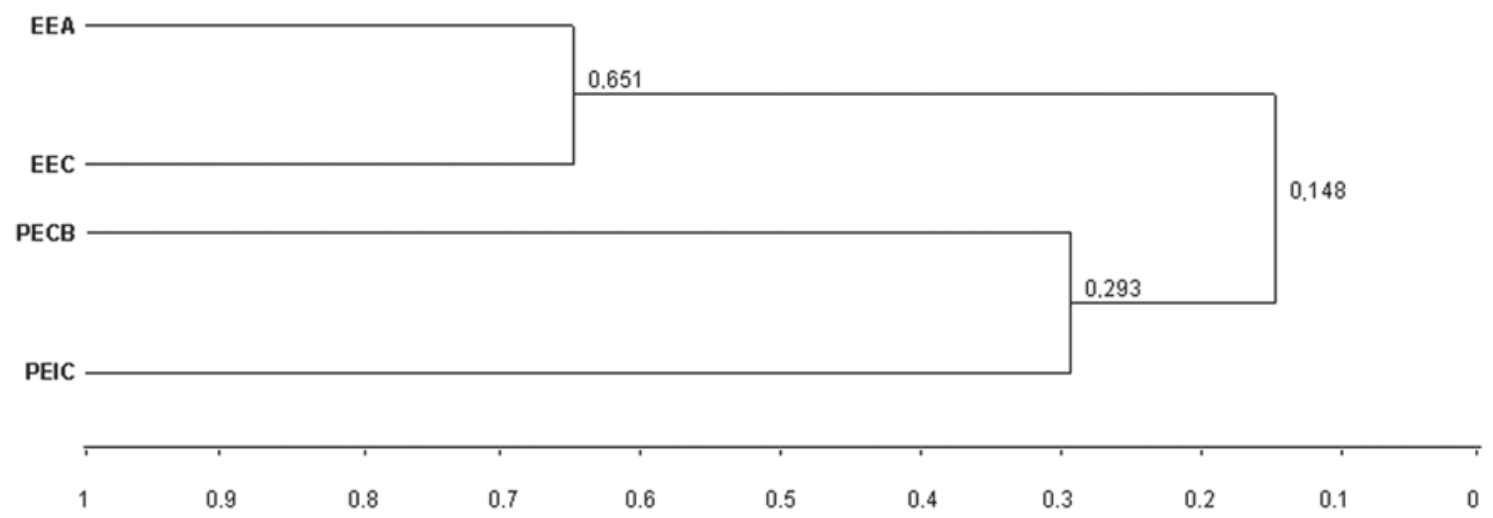

Figure 2 - Cluster analysis of four sites based on their similarities (CGR) in anuran species composition (cophenetic correlation coefficient $=0.9482$ ). Legend: EEA, Estação Ecológica de Assis; EEC, Estação Ecológica de Caetetus; PECB, Parque Estadual de Carlos Botelho; PEIC, Parque Estadual da Ilha do Cardoso. 
Table 1 - Anuran species collected in four forest sites of southeastern Brazil between September 2005 and September 2006. EEA, Estação Ecológica de Assis; EEC, Estação Ecológica de Caetetus; PECB, Parque Estadual de Carlos Botelho; PEIC, Parque Estadual da Ilha do Cardoso.

\begin{tabular}{|c|c|c|c|c|}
\hline & EEA & EEC & PECB & PEIC \\
\hline \multicolumn{5}{|l|}{ BRACHYCEPHALIDAE } \\
\hline Eleutherodactylus binotatus (Spix, 1824) & & $\mathrm{X}$ & $\mathrm{X}$ & $\mathrm{X}$ \\
\hline Eleutherodactylus guentheri (Steindachner, 1864) & & & $\mathrm{X}$ & \\
\hline \multicolumn{5}{|l|}{ BUFONIDAE } \\
\hline Chaunus ictericus (Spix, 1824) & & & $\mathrm{X}$ & \\
\hline Chaunus ornatus (Spix, 1824) & & $\mathrm{X}$ & $\mathrm{X}$ & $\mathrm{X}$ \\
\hline Chaunus schneideri (Werner, 1894) & $\mathrm{X}$ & $\mathrm{X}$ & & \\
\hline Dendrophryniscus brevipollicatus Jiménez de la Espada, 1871 & & & $\mathrm{X}$ & \\
\hline Dendrophryniscus leucomystax Izecksohn, 1968 & & & & $\mathrm{X}$ \\
\hline Rhinella margaritifer (Laurenti, 1768) & & & $\mathrm{X}$ & \\
\hline \multicolumn{5}{|l|}{ CYCLORAMPHIDAE } \\
\hline Cycloramphus sp. & & & $\mathrm{X}$ & \\
\hline Odontophrynus americanus (Duméril \& Bibron, 1841) & $\mathrm{X}$ & $\mathrm{X}$ & & \\
\hline Proceratophrys boiei (Wied-Neuwied, 1824) & & & $\mathrm{X}$ & \\
\hline \multicolumn{5}{|l|}{ HYLIDAE } \\
\hline Aparasphenodon bokermanni Pombal, 1993 & & & & $\mathrm{X}$ \\
\hline Bokermannohyla hylax (Heyer, 1985) & & & $\mathrm{X}$ & \\
\hline Dendropsophus berthalutzae (Bokermann, 1962) & & & & $\mathrm{x}$ \\
\hline Dendropsophus decipiens (A. Lutz, 1925) & & & & $\mathrm{X}$ \\
\hline Dendropsophus elegans (Wied-Neuwied, 1824) & & & $\mathrm{X}$ & \\
\hline Dendropsophus minutus (Peters, 1872) & $\mathrm{X}$ & $\mathrm{X}$ & $\mathrm{X}$ & \\
\hline Dendropsophus nanus (Boulenger, 1889) & $\mathrm{X}$ & $\mathrm{X}$ & & \\
\hline Dendropsophus seniculus (Cope, 1868) & & & $\mathrm{X}$ & \\
\hline Hypsiboas albomarginatus (Spix, 1824) & & & $\mathrm{X}$ & $\mathrm{X}$ \\
\hline Hypsiboas albopunctatus (Spix, 1824) & $\mathrm{X}$ & $\mathrm{X}$ & & \\
\hline Hypsiboas bischoffi (Boulenger, 1887) & & & $\mathrm{X}$ & \\
\hline Hypsiboas caingua (Carrizo, 1991 "1990") & & $\mathrm{X}$ & & \\
\hline Hypsiboas faber (Wied-Neuwied, 1821) & $\mathrm{X}$ & $\mathrm{X}$ & $\mathrm{X}$ & $\mathrm{X}$ \\
\hline Hypsiboas lundii (Burmeister, 1856) & $\mathrm{X}$ & $\mathrm{X}$ & & \\
\hline Hypsiboas semilineatus (Spix, 1824) & & & $\mathrm{X}$ & \\
\hline Itapotihyla langsdorffii (Duméril \& Bibron, 1841) & & $\mathrm{X}$ & & $\mathrm{X}$ \\
\hline Phyllomedusa distincta A. Lutz in B. Lutz, 1950 & & & $\mathrm{X}$ & \\
\hline Phyllomedusa tetraploidea Pombal \& Haddad, 1992 & $\mathrm{X}$ & $\mathrm{X}$ & & \\
\hline Scinax alter (B. Lutz, 1973) & & & $\mathrm{X}$ & \\
\hline Scinax argyreornatus (Miranda-Ribeiro, 1926) & & & & $\mathrm{X}$ \\
\hline Scinax cuspidatus (A. Lutz, 1925) & & & & $\mathrm{X}$ \\
\hline Scinax fuscomarginatus (A. Lutz, 1925) & $\mathrm{X}$ & & & \\
\hline Scinax fuscovarius (A. Lutz, 1925) & $\mathrm{X}$ & $\mathrm{X}$ & & \\
\hline Scinax hayii (Barbour, 1909) & & & $\mathrm{X}$ & \\
\hline Scinax littoralis (Pombal \& Gordo, 1991) & & & $\mathrm{X}$ & \\
\hline Scinax rizibilis (Bokermann, 1964) & & $\mathrm{X}$ & $\mathrm{X}$ & \\
\hline Scinax $x$-signatus (Spix, 1824) & & $\mathrm{X}$ & & \\
\hline
\end{tabular}


Table 1 - Continuation.

Scinax sp.

HYLODIDAE

Hylodes sp. (gr. lateristrigatus)

$\mathrm{X}$

Hylodes phyllodes Heyer \& Cocroft, 1986

LEIUPERIDAE

Eupemphix nattereri (Steindachner, 1863)

Physalaemus moreirae (Miranda-Ribeiro, 1937)

Physalaemus cuvieri Fitzinger, 1826

Physalaemus fuscomaculatus (Steindachner, 1864)

Physalaemus olfersii (Lichtenstein \& Martens, 1856)

Physalaemus spiniger (Miranda-Ribeiro, 1926)

LEPTODACTYLIDAE

Leptodactylus fuscus (Schneider, 1799)

Leptodactylus labyrinthicus (Spix, 1824)

Leptodactylus marmoratus (Steindachner, 1867)

Leptodactylus mystaceus (Spix, 1824)

Leptodactylus mystacinus (Burmeister, 1861)

Leptodactylus notoaktites Heyer, 1978

Leptodactylus ocellatus (Linnaeus, 1758)

Leptodactylus podicipinus (Cope, 1862)

MICROHYLIDAE

Chiasmocleis albopunctata (Boettger, 1885)

Chiasmocleis leucosticta (Boulenger, 1888)

Elachistocleis bicolor (Valenciennes in Guérin-Menéville, 1838)

Elachistocleis ovalis Schneider, 1799

Myersiella microps (Duméril \& Bibron, 1841)

Number of species

Table 2 - Similarities in anuran composition among sites expressed by the index of similarity of Jaccard (italics) and the Coefficient of Geographical Resemblance (Duellman 1990) (bold). Numbers in brackets are indexes of Jaccard calculated for similarities among sites in tree species (Rodrigues, 2003).

\begin{tabular}{lcccc}
\hline & EEA & EEC & PECB & PEIC \\
\hline EEA & & $\mathbf{0 . 6 5 1 2}$ & $\mathbf{0 . 0 8 7 0}$ & $\mathbf{0 . 0 6 0 6}$ \\
EEC & $0.4828(0.0535)$ & & $\mathbf{0 . 2 3 5 3}$ & $\mathbf{0 . 2 1 0 5}$ \\
PECB & $0.0455(0.0352)$ & $0.1333(0.0951)$ & & $\mathbf{0 . 2 9 2 7}$ \\
PEIC & $0.0312(0.0654)$ & $0.1176(0.0537)$ & $0.1714(0.1289)$ &
\end{tabular}

sites belonging to the same domain ( $\mathrm{f}=9.9025, \mathrm{R}^{2}=$ 64.04\%, $P=0.0351$ ) (Figure 3). Gamma diversity was higher in the Atlantic Forest Domain sites (PECB+PEIC, 38 species) than in Cerrado-CaatingaChaco Domain sites (EEA+EEC, 29 species) (Table 1). Beta diversity was also higher in the Atlantic Forest Domain sites (1.72) than in Cerrado-Caatinga-Chaco Domain sites (1.35).

The dendrogram obtained from cluster analysis of all Brazilian sites used here for comparisons (Fig- ure 4) evidences three major groups: (A) sites located in the Atlantic coastal ranges and interior highlands (PECB and sites 3, 6, 7 and 8), (B) sites in the lowlands of the Atlantic Coastal Forest (PEIC and sites 9 and 10 ), and (C) sites belonging to the Cerrado domain or the transition Cerrado-Atlantic Forest (EEA, EEC, and sites 1, 2, 4, and 5). The Serra do Japi grouped with Atlantic rainforest localities despite being considered a semideciduous forest. This fact reveals the transitional character of the area (Leitão- 
Filho, 1992). Distance among sites explains a small part of similarities between pairs of sites belonging to the same domain ( $\mathrm{f}=27.8783, \mathrm{R}^{2}=23.00 \%, P=0.0000$ ) (Figure 5). The pattern of similarity among sites included in group A is exactly the same as the one ob-

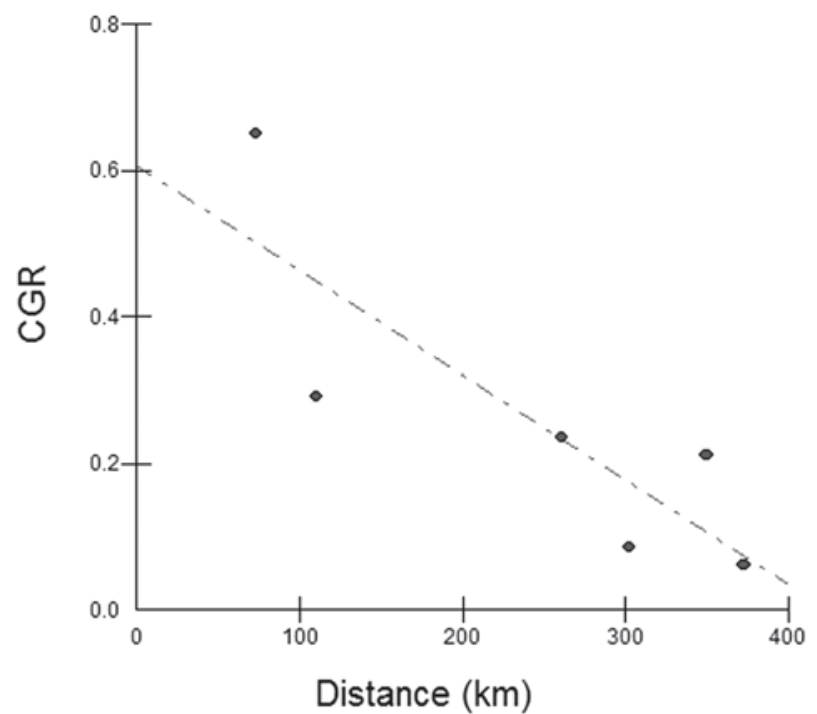

Figure 3 - Relationship between similarities in anuran species composition (CGR) and geographical distance for four forest sites of southeastern Brazil ( $f=9.9025, R^{2}=$ 0.64, $\left.P=0.0351 ; Y^{\prime}=0.6069-0.0014 \mathrm{X}\right)$. tained by Dixo \& Verdade (2006) when comparing the leaf litter anurans. Dixo \& Verdade (2006) suggested that similarities among sites reflect differences inherent to distinct geomorphological formations: Serra do Mar (sites 6 and 8), interior Atlantic highlands (site 7 and PECB), and Serra da Mantiqueira (site 3).

Species shared by sites belonging to different domains are wide-ranging species, like Dendropsophus minutus and Leptodactylus ocellatus (IUCN, Conservation International \& NatureServe, 2006). Wide-ranging species recorded only at sites belonging to the Cerrado domain (EEA and EEC) - the hylids Hypsiboas albopunctatus and $S$. fuscovarius, the leptodactylids $L$. fuscus, L. labyrinthicus, L. mystacinus, the leiuperid $P$. cuvieri, and the cycloramphid Odontophrynus americanus - are expected to occur also in PECB, since they were found in other studies carried out in Atlantic Forest sites (Heyer et al., 1990; Guix et al., 1994; 2000; Bertoluci, 1998; Bertoluci \& Rodrigues, 2002a; 2002b; Pombal Jr. \& Gordo, 2004). The presence of some of these species may represent recent colonization due to human interference, as postulated to Estação Biológica de Boracéia (Heyer et al., 1988; 1990; Bertoluci \& Heyer, 1995) and PECB (Guix et al., 1994; 2000). These species were not recorded in

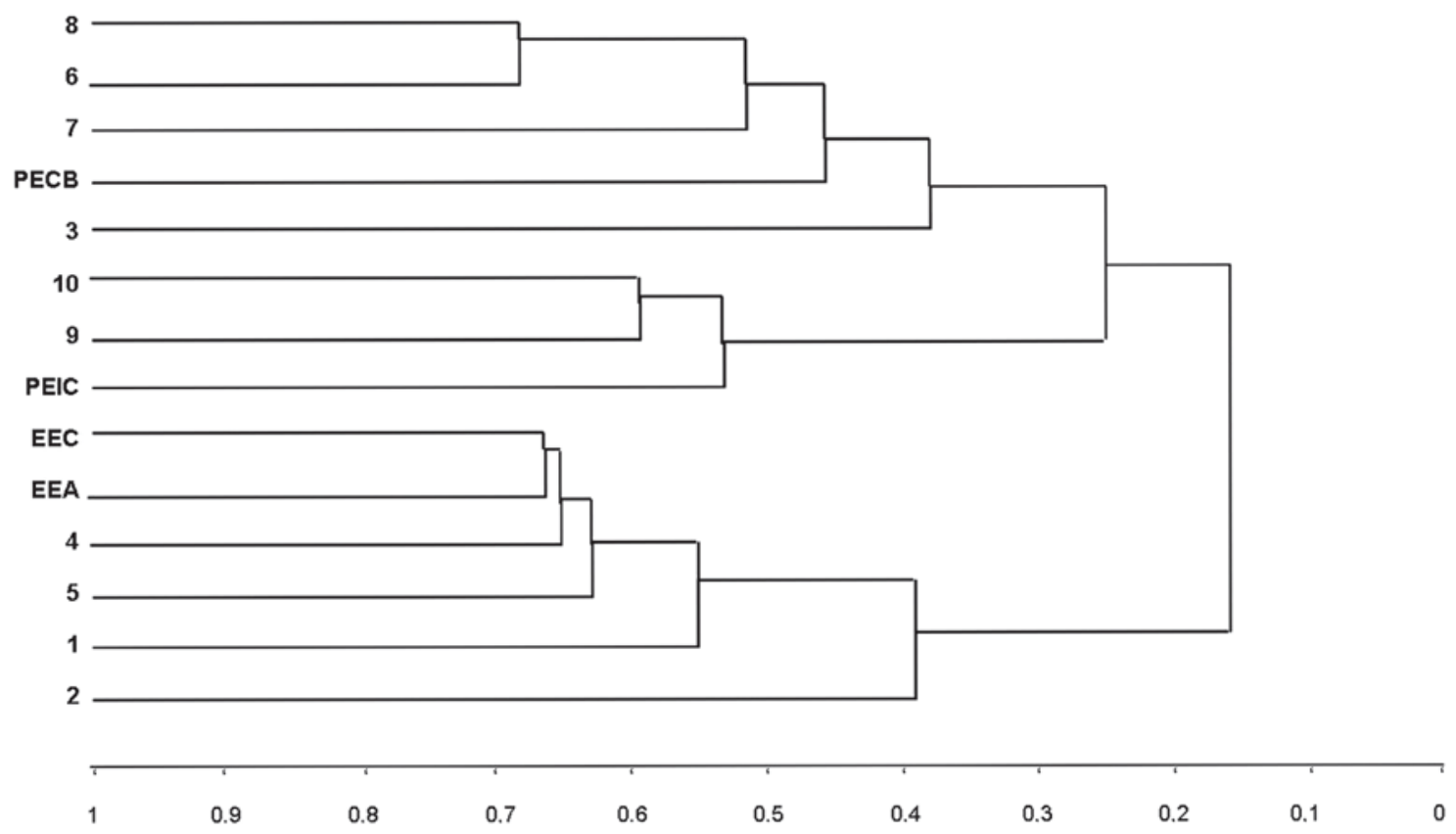

Figure 4 - Cluster analysis of 14 Brazilian sites based on their similarities (CGR) in anuran species composition (cophenetic correlation coefficient = 0.8880). Legend: EEA, Estação Ecológica de Assis; EEC, Estação Ecológica de Caetetus; PECB, Parque Estadual de Carlos Botelho; PEIC, Parque Estadual da Ilha do Cardoso; 1. Estação Ecológica de Itirapina (Brasileiro et al., 2005$) ; 2$. Floresta Nacional de Silvânia (Bastos et al., 2003); 3. Serra do Japi (Haddad \& Sazima, 1992; Ribeiro et al., 2005); 4. Botucatu (Rossa-Feres \& Jim, 1994); 5. Parque Estadual Mata dos Godoy, Londrina (Bernarde \& Anjos, 1999); 6. Estação Biológica de Boracéia (Heyer et al., 1990; Bertoluci et al., 2005); 7. Parque Estadual de Intervales (Bertoluci, 1998); 8. Reserva Biológica de Paranapiacaba (Vanessa K. Verdade, pers. commun.); 9. Estação Biológica Juréia-Itatins, Rio Verde (Pombal Jr. \& Gordo, 2004); 10. Estação Biológica Juréia-Itatins, Guarauzinho (Narvaes, 1993). 


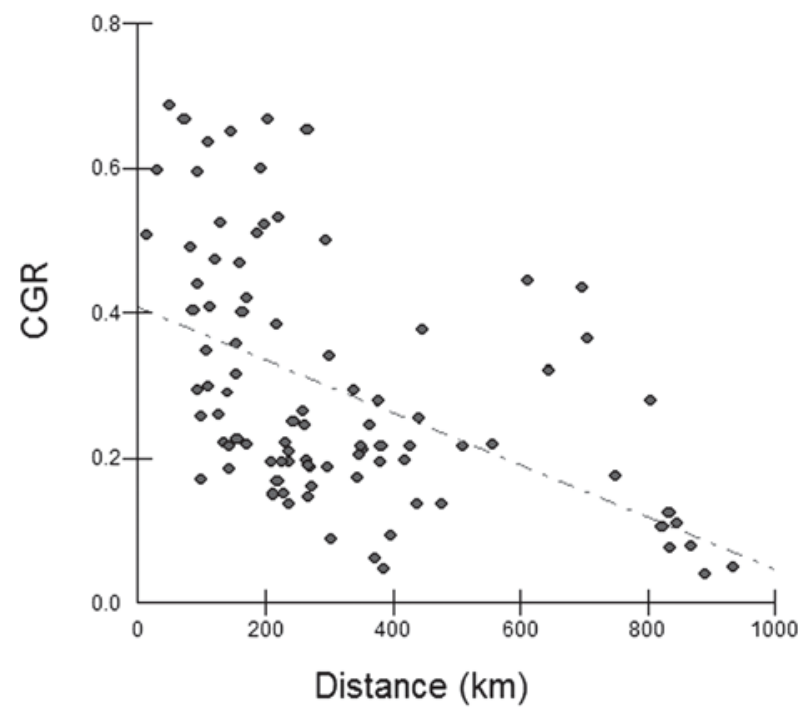

Figure 5 - Relationship between similarity in anuran species composition (CGR) and geographical distance for 14 sites of southeastern Brazil ( $\mathrm{f}=27.8783, \mathrm{R}^{2}=0.23$, $\left.P=0.0000 ; Y^{\prime}=0.4089-0.0004 X\right)$.

that site probably due to the fact that the field work conducted in PECB focused mainly in forest areas rather than open ones or forest edges.

The presence of typical Atlantic forest species (Physalaemus olfersii, Scinax rizibilis, Itapotihyla langsdorffii, Chaunus ornatus, and Eleutherodactylus binotatus) in EEC suggests that this site is zoogeographically under influence of the Atlantic Forest Domain. The Atlantic Forest Domain is a hotspot of species richness and endemism, with more than 322 anuran species, whereas 300 of them (93\%) are endemic (Duellman, 1999). This pattern is typical of several Atlantic rainforest sites of southeastern Brazil (e.g. Heyer et al., 1990; Guix et al., 1994; Bertoluci \& Rodrigues, 2002b) and it seems to be associated to topography, climate, and structural complexity of vegetation.

Topography is a major factor determining high degrees of species richness and endemism: $53.4 \%$ of all South American anurans (985 species, 930 endemics) live in highland regions which correspond to only $15.5 \%$ of the area of the continent (Duellman, 1999). A narrow climatic variability determines the selection of a narrower range of altitudes by anurans, which leads to higher endemism (Lynch, 1986; Duellman, 1999). In the mountain ranges of southeastern Brazil the complex relief of Serra do Mar and Serra da Mantiqueira promoted geographical isolation of populations and favored speciation and endemism (Haddad, 1998).

The diversity of amphibians is highly correlated with moisture due to their permeable skin and their shell-less eggs, and anuran species with reproductive modes dependent on high atmosphere humidity are most abundant at sites with heavy rainfall (Duellman \& Trueb, 1986; Duellman \& Thomas, 1996; Duellman, 1999). Data here collected corroborate this pattern. Mean annual temperature is high in all sites and mean annual rainfall in PECB and PEIC is higher than in EEA and EEC. Mean air relative humidity is 72.2 and $74.1 \%$ in EEA and EEC and 89.1 and $84.4 \%$ in PECB and PEIC, respectively. The lower number of species recorded in PEIC when compared to EEC and EEA could be attributed to a combination of flat relief and physical and chemicals factors, including high temperatures and salinity (Ormond, 1960; Franco et al., 1984).

The great structural diversity of tropical forests could explain their high levels of frog richness and endemism. Different strata (e.g. understory, canopy, epiphytes, vines) house a great diversity of potential prey, which determines a more diverse fauna of arboreal frogs (Pough et al., 1998) and provide a great variety of microhabitats associated with specialized reproductive modes (Haddad \& Prado, 2005). Additionally, mountain streams of Atlantic forest house several endemic hylodids of genera Hylodes, Crossodactylus and Megaelosia (Duellman, 1999), whose activities are restricted to these habitats.

No species in the areas is included in the IBAMA ("Instituto Brasileiro do Meio Ambiente e dos Recursos Naturais Renováveis", the Brazilian governmental agency for the environment and natural resources) list of Brazilian threatened amphibians (Machado et al., 2005), but it must be considered that there are two Brazilian lists containing two very different sets of threatened species: the IBAMA list with 24 species and the GAA list including 110 species (Baillie et al., 2004; Stuart et al., 2005). If its identity is confirmed, Physalaemus cf. moreirae recorded at PECB will be included in GAA list as Data Deficient but it might be considered of Least Concern by the IBAMA list. Discrepancy between both lists reflects two different attitudes towards conservation status assessment, an evidentiary (IBAMA) and a precautionary point of view (GAA) (Baillie et al., 2004, Pimenta et al., 2005, Stuart et al., 2005). The GAA attitude is here preferred because this species is endemic to Atlantic rainforest, which is severely divided into small $\left(<7,000 \mathrm{~km}^{2}\right)$ isolated fragments, with only $3,000 \mathrm{~km}^{2}$ of forest included in protected areas (Brooks \& Balmford, 1996). Additionaly, the remnants of Atlantic forest of southeastern Brazil are under high levels of UVB incidence and have highly projected future effects of climatic change, and some species were infected by the fungus Batrachochytrium dendrobatidis (Carnaval et al., 2005; 2006; Toledo et al., 2006). 
Some species are excellent bioindicators of habitat quality due to their dependence on special microhabitats and microclimatic conditions. Eleutherodactylus binotatus and E. guentheri lay eggs that undergo direct development on the leaf litter (Lynn \& Lutz, 1946; Thibaudeau \& Altig, 1999), tadpoles of Leptodactylus marmoratus develop out of water in a terrestrial foam nest (Heyer, 1973), and some species of Cycloramphus lay eggs in terrestrial situations (Haddad \& Sazima, 1989; Verdade \& Rodrigues, 2003). Richness of species of the genus Eleutherodactylus in Equatorian Amazonia decreased in deforested areas, probably due to microclimate changes (Pearman, 1997). Many anurans use bromeliads as refuge and for forrage and reproduction (BrittoPereira et al., 1988; Peixoto, 1995; Oliveira \& Rocha, 1997; Schineider \& Teixeira, 2001), and some species depend on water accumulated in these plants for oviposition and tadpole development. In our sites species associated with bromeliads include Dendrophryniscus brevipollicatus (Carvalho, 1949), registered in PECB, and Scinax argyreornatus and Aparasphenodon bokermanni from PEIC.

The presence of anurans with specific ecological and reproductive requirements in the study sites suggests the presence of healthy ecosystems that must be preserved.

\section{ACKNOWLEDGEMENTS}

To Vanessa K. Verdade for helping in species identification, Regina C. Vincent for helping with cluster analysis, Paula C. Lopes, Leonardo Ramos Adriano, Thiago S. Marques, Mariana Piva da Silva, Gabriel Dalla Coleta, Marcus V. L. Pereira, Delcides Brassaloti Neto, Bruno H. C. Cavichioli, Gabriel L. Brejão, Paulo R. Garcia, Joyce Rodrigues do Prado, Neliton R. F. Lara and Pablo H. F. Lastra for helping in the field activities, Axel Kwet, Ron Heyer and Denise de C. Rossa-Feres for comments and suggestions on the manuscript, IBAMA for providing license of collection ( $n^{\circ} 430 / 05$ ), Instituto Florestal for authorizing field work within the conservation units, and FAPESP for financial support (processes $n^{\circ}$ 04/15938-5 and 99/09635-0). To CNPq for the research scholarship of Jaime Bertoluci.

\section{REFERENCES}

AB'SABER, A.N. Os domínios morfo-climáticos na América do Sul. Primeira aproximação. Geomorfologia, v.52, p.1-22, 1977. AYRES, M.; AYRES JR., M.; AYRES, D.L.; SANTOS, A.S. BioEstat 3.0 - aplicações estatísticas nas áreas das ciências biológicas e médicas. Belém: Sociedade Civil Mamirauá / MCT-CNPq / Conservation International, 2003. 291p.

BAILLIE, J.E.M.; HILTON-TAYLOR, C.; STUART, S.N. A global species assessment. Gland: IUCN, 2004.
BASTOS, R.P.; MOTTA, J.A.O.; LIMA, L.P.; GUIMARÃES, L.D. Anfíbios da Floresta Nacional de Silvânia, Estado de Goiás. Goiânia: Stylo Gráfica e Editora, 2003. 82p.

BERNARDE, P.S.; ANJOS, L. Distribuição espacial e temporal da anurofauna no Parque Estadual Mata dos Godoy, Londrina, Paraná, Brasil (Amphibia: Anura). Comunicações do Museu de Ciências e Tecnologia. Série Zoologia, v.12, p.127-140, 1999.

BERNARDE, P.S.; KOKUBUM, M.N.C. Anurofauna do Município de Guararapes, estado de São Paulo, Brasil (Amphibia: Anura). Acta Biológica Leopoldensia, v.21, p.89-97, 1999.

BERNARDE, P.S.; MACHADO, R.A. Riqueza de espécies, ambientes de reprodução e temporada de vocalização da anurofauna em Três Barras do Paraná, Brasil (Amphibia: Anura). Cuadernos de Herpetologia, v.14, p.93-104, 2001.

BERTOLUCI, J. Annual patterns of breeding activity in Atlantic Rainforest anurans. Journal of Herpetology, v.32, p.607-611, 1998.

BERTOLUCI, J.; HEYER, W.R. Boracéia update. Froglog, v.14, p.2-3, 1995.

BERTOLUCI, J.; RODRIGUES, M.T. Utilização de hábitats reprodutivos e micro-hábitats de vocalização em uma taxocenose de anuros (Amphibia) da Mata Atlântica do sudeste do Brasil. Papéis Avulsos de Zoologia, v.42, p.287-297, 2002a.

BERTOLUCI, J.; RODRIGUES, M.T. Seasonal patterns of breeding activity of Atlantic rainforest anurans at Boracéia, Southeastern Brazil. Amphibia-Reptilia, v.23, p.161-167, 2002b.

BERTOLUCI, J.; VERDADE, V.K.; RODRIGUES, M.T.; PAVAN, D.; LIOU, N.L.; LANGE, M.C. Anuros da Estação Biológica de Boracéia: 25 anos após declínios. In: CONGRESSO BRASILEIRO DE HERPETOLOGIA, 2., Belo Horizonte, 2005. Resumos. Belo Horiaonte, 2005. 1 CD-ROM.

BRASILEIRO, C.A.; SAWAYA, R.J.; KIEFER, M.C.; MARTINS, M. Amphibianns of an open cerrado fragment in southeastern Brazil. Biota Neotropica, v.5, 2005. Available on: http:// www.biotaneotropica.org.br/v5n2/pt/abstract?article+ BN00405022005.

BRITTO-PEREIRA, M.C.; CERQUEIRA, R.; SILVA, H.R.; CARAMASCHI, U. Anfíbios anuros da restinga de Barra de Maricá, RJ: levantamento e observações preliminares sobre a atividade reprodutiva das espécies registradas. In: SEMINÁRIO REGIONAL DE ECOLOGIA, 5., São Carlos, 1988. Anais. São Carlos: UFSCar, 1988. p.295-306.

BROOKS, T.; BALMFORD, A. Atlantic forest extinctions. Nature, v.380, p.115, 1996.

CARNAVAL, A.C.O.Q.; PUSCHENDORF, R.; PEIXOTO, O.L.; VERDADE, V.K.; RODRIGUES, M.T. Amphibian chytrid fungus broadly distributed in the Brazilian Atlantic Rain forest. Ecohealth. 2006. Available on: DOI: 10.1007/s10393-005-0008-2).

CARNAVAL, A.C.O.Q.; TOLEDO, L.F.; HADDAD, C.F.B.; BRITTO, F.B. Chytrid fungus infects high altitude streamdwelling Hylodes magalhaesi (Leptodactylidae) in the Brazilian Atlantic Rainforest. Froglog, v.70, p.3, 2005.

CARVALHO, A.L. Notas sobre os hábitos de Dendrophryniscus brevipollicatus Espada (Amphibia, Anura). Revista Brasileira de Biologia, v.9, p.223-227, 1949.

CRUMP, M.L. Quantitative analysis of the ecological distribution of a tropical herpetofauna. Lawrence: University of Kansas, 1971. 62p. (Occasional Papers of the Museum of Natural History, 3).

CRUMP, M.L.; SCOTT JR., N.J. Visual encounter surveys. In: HEYER, W.R.; DONNELLY, M.A.; MCDIARMID, R.W.; HAYEK, L.-A.C.; FOSTER, M.S. (Ed.). Measuring and monitoring biological diversity: standard methods for amphibians. Washington: Smithsonian Institution Press, 1994. p.84-92.

DIXO, M.; VERDADE, V.K. Herpetofauna de serrapilheira da Reserva Florestal de Morro Grande, Cotia (SP). Biota Neotropica, v.6, 2006. Available on: http://www.biotaneotropica.org.br/v6n2/ pt/abstract?article+bn00806022006. 
DOMINGUES, E.N.; SILVA, D.A. Geomorfologia do Parque Estadual de Carlos Botelho (SP). Boletim Técnico do Instituto Florestal, v.42, p.71-105, 1988.

DUELLMAN, W.E. Herpetofauna in neotropical rainforests: comparative composition, history, and resource utilization. In: GENTRY, A.H. (Ed.). Four neotropical rainforests. New Haven: Yale Univ. Press, 1990. p.455-505.

DUELLMAN, W.E. Distribution patterns of amphibians in South America. In: DUELlMAN, W.E. (Ed.). Patterns of distribution of amphibians - a global perspective. Baltimore: The Johns Hopkins University Press, 1999. p.255-328.

DUELLMAN, W.E.; THOMAS, R. Anuran amphibians from a seasonal dry forest in southeastern Peru and comparisons of the anurans among sites in the upper Amazon Basin. Lawrence: University of Kansas, 1996. 34p. (Occasional Papers of the Natural History Museum, 180).

DUELLMAN, W.E.; TRUEB, L. Biology of Amphibians. Baltimore: The Johns Hopkins University Press, 1986. 670p.

ETEROVICK, P.C.; CARNAVAL, A.C.O.Q.; BORGES-NOJOSA, D.M.; SILVANO, D.; SEGALLA, M.V.; SAZIMA, I. Amphibian declines in Brazil: an overview. Biotropica, v.37, p.166-179, 2005.

FEARNSIDE, P.M. Predominant land use in Brazilian Amazonia. In: ANDERSON, A. (Ed.). Alternatives to deforestation: steps toward sustainable use of the Amazon rainforest. Irvington: Columbia Univ. Press, 1990. p.233-251.

FEARNSIDE, P.M. Brazil. In: HARCOURT, C.S.; SAYER, J.A. (Ed.). The conservation atlas of tropical forests: the Americas. New York: Simon and Schuster, 1996.

FRANCO, A.C.; VALERIANO, D.M.; SANTOS, F.M.; HAY, J.D.; HENRIQUES, R.P.B.; MEDEIROS, R.A. Os microclimas das zonas de vegetação da praia da restinga de Barra de Maricá, Rio de Janeiro. In: LACERDA, L.D.; ARAUJO, D.S.D.; CERQUEIRA, R.; TURCQ, B. (Orgs.). Restingas: Origem, estrutura e processos. Niterói: CEUFF, 1984. p.413-425.

FROST, D.R.; GRANT, T.; FAIVOVICH, J.; BAIN, R.H.; HAAS, A.; HADDAD, C.F.B.; SÁ, R.O.de; CHANNING, A.; WILKINSON, M.; DONNELLAN, S.C.; RAXWORTHY, C.J.; CAMPBELL, J.A.; BLOTTO, B.L.; MOLER, P.; DREWES, R.C.; NUSSBAUM, R.A.; LYNCH, J.D.; GREEN, D.M.; WHEELER, W.C. The amphibian tree of life. Bulletin of the American Museum of Natural History, v.297, p.1-370, 2006.

GASCON, C. Population-and community-level analyses of species occurrences of central amazonian rainforest tadpoles. Ecology, v.72, p.1731-1746, 1991.

GRANT, T.; FROST, D.R.; CALDWELL, J.P.; GAGLIARDO, R.; HADDAD, C.F.B.; KOK, P.J.R.; MEANS, D.B.; NOONAN, B.P.; SCHARGEL, W.E.; WHEELER, W.C. Phylogenetic systematics of Dart-Poison frogs and their relatives (Amphibia: Athesphatanura: Dendrobatidae). Bulletin of the American Museum of Natural History, v.299, p.1-154, 2006.

GUIX, J.C.; NUNES, V.S.; MIRANDA, J.R. Autochthonous and colonizing species of frogs in Carlos Botelho State Reserve, southeastern Brazil. Boletin de la Asociación Herpetológica Española, v.5, p.8-13, 1994.

GUIX, J.C.; LLORENTE, G.; MONTORI, A.; CARRETERO, M.A.; SANTOS, X. Uma nueva área de elevada riqueza de anuros em el Bosque Lluvioso Atlántico de Brasil. Boletin de la Asociación Herpetológica Española, v.11, p.100-105, 2000.

HADDAD, C.F.B. Biodiversidade dos anfíbios do Estado de São Paulo. In: CASTRO, R.M.C. (Ed.). Biodiversidade do Estado de São Paulo, Brasil: síntese do conhecimento ao final do século XX. São Paulo: Editora FAPESP, 1998. v.6, p.17-26.

HADDAD, C.F.B.; PRADO, C.P.A.. Reproductive modes in frogs and their unexpected diversity in the Atlantic forest of Brazil. BioScience, v.55, p.207-217, 2005.

HADDAD, C.F.B.; SAZIMA, I. A new species of Cycloramphus from southeastern Brazil (Amphibia, Leptodactylidae). Herpetologica, v.45, p.425-429, 1989.
HADDAD, C.F.B.; SAZIMA, I. Anfíbios anuros da Serra do Japi. In: MORELLATTO, L.P.C. (Org.). História Natural da Serra do Japi: ecologia e preservação de uma área florestal no Sudeste do Brasil. Campinas: Editora da Unicamp/FAPESP, 1992. p.188211.

HERO, J.M. An illustrated key to tadpoles occurring in the Central Amazon rainforest, Manaus, Amazonas, Brasil. Amazoniana, v.11, p.201-262, 1990

HEYER, W.R. Systematics of the marmoratus group of the frog genus Leptodactylus (Amphibia, Leptodactylidae). Contributions in Science, n.251, p.1-50, 1973.

HEYER, W.R.; RAND, A.S.; CRUZ, C.A.G.; PEIXOTO, O.L. Decimations, extinctions, and colonizations of frog populations in southeast Brazil and their evolutionary implications. Biotropica, v.20, p.230-235, 1988.

HEYER, W.R.; RAND, A.S.; CRUZ, C.A.G.; PEIXOTO, O.L.; NELSON, C.E. Frogs of Boracéia. Arquivos de Zoologia, v.31, p.231-410. 1990.

HEYER, W.R.; DONNELLY, M.A.; MACDIARMID, R.W.; HAYEK, L-A.C.; FOSTER, M.S. (Ed.). Measuring and monitoring biological diversity - Standard methods for amphibians. Washington: Smithsonian Institution Press, 1994.

IUCN. Conservation International and NatureServe. Global amphibian assessment. Available on: <www.globalamphibians.org>. Accessed on: 2 Oct. 2006.

LEITÃO-FILHO, H.F. A flora arbórea da Serra da Japi. In: MORELLATTO, L.P.C. (org.) História Natural da Serra do Japi: ecologia e preservação de uma área florestal no Sudeste do Brasil. Campinas: Editora da Unicamp; FAPESP, 1992, p.40-62.

LYNCH, J.D. Origins of the high Andean herpetological fauna. In: VUILleUMIER, F.; MONASTERIO, M. (Ed.). High altitude tropical biogeography. New York: Oxford University Press, 1986. p.478-499.

LYNN, W.G.; LUTZ, B. The development of Eleutherodactylus guentheri Stdnr., 1864 (Salientia). Boletim do Museu Nacional de Zoologia, v.71, p.1-46, 1946.

MACHADO, A.B.M.; MARTINS, C.S.; DRUMMOND, G.M. Lista da fauna brasileira ameaçada de extinção. Belo Horizonte: Fundação Biodiversitas, 2005.

MACHADO, R.A.; BERNARDE, P.S.; MORATO S.S.A.; ANJOS, L. Análise comparada da riqueza de anuros entre duas áreas com diferentes estados de conservação no município de Londrina, Paraná, Brasil (Amphibia: Anura). Revista Brasileira de Zoologia, v.16, p.997-1004, 1999.

MYERS, N. Tropical deforestation and a mega-extinction spasm. In: SOULÉ, M.E. (Ed.). Conservation biology: the science of scarcity and diversity. Sunderland: Sinauer Associates, 1986. p.394-409.

NARVAES, P. Distribuição espacial e temporal de anfíbios (Anura) de Mata Atlântica durante a atividade reprodutiva. São Paulo: USP/IB, 1993. 24p. (Undergraduate Monograph.).

OLIVEIRA, M.G.N.; ROCHA, C.F.D. O efeito da complexidade da bromélia-tanque Neoregelia cruenta (R. GRAHAM) L.B. SMITH sobre a comunidade animal associada. Bromélia, v.4, p.13-22, 1997.

ORMOND, W.T. Ecologia das restingas do Sudeste do Brasil: comunidades vegetais das praias arenosas. Parte I. Arquivos do Museu Nacional, v.50, p.185-236, 1960.

PEARMAN, P.B. Correlates of amphibian diversity in an altered landscape of Amazonian Ecuador. Conservation Biology, v.11, p.1211-1225, 1997 .

PECHMANN, J.H.K.; SCOTT, D.E.; SEMLITSCH, R.D.; CALDWELL, J.P.; VITT, L.J.; GIBBONS, J.W. Declining amphibians populations: the problem of separating human impacts from natural fluctuations. Science, v.253, p.892-895, 1991.

PEIXOTO, O.L. Associação de anuros a bromeliáceas na mata Atlântica. Revista da Universidade Rural, v.17, p.75-83, 1995. (Série Ciências da Vida). 
PIMENTA, B.V.S.; HADDAD, C.F.B.; NASCIMENTO, L.B.; CRUZ, C.A.G.; POMBAL JR., J.P. Comment on "Status and trends of amphibian declines and extinctions worldwide". Science, v.309, p.1999b, 2005.

POMBAL JR., J.P.; GORDO, M. Anfíbios anuros da Juréia. In: MARQUES, O.A.V.; DULEBA, W. Estação Ecológica JuréiaItatins. Ambiente físico, flora e fauna. Ribeirão Preto: Holos, 2004. p.243-256.

POUGH, F.H.; ANDREWS, R.M.; CADLE, J.E.; CRUMP, M.L.; SAVITZKY, A.H.; WELLS, K.D. Herpetology. Upper Saddle River: PrenticeHall, 1998. 577p.

PRIMACK, R.B. Essentials of conservation biology. Sunderland: Sinauer Associates, 1998. 660p.

RIBEIRO, R.S.; EGITO, G.T.B.T.; HADDAD, C.F.B. Chave de identificação: anfíbios anuros da vertente de Jundiaí da Serra do Japi, estado de São Paulo. Biota Neotropica, v.5, p.1-15, 2005.

RODRIGUES, R.R. (Org.). SIMPÓSIO INTERNO DO PROJETO PARCELAS PERMANENTES, Assis, 2003. $2^{\circ}$ Relatório.

ROSSA-FERES, D.C.; JIM, J. Distribuição sazonal em comunidades de anfíbios anuros na região de Botucatu, São Paulo. Revista Brasileira de Biologia, v.54, p.323-334, 1994.

SCHINEIDER, J.A.P.; TEIXEIRA, R.L. Relationship between anuran amphibians and bromeliads of the sandy coastal plain of Regência, Linhares, Espírito Santo, Brazil. Iheringia. Série Zoologia, v.91, p.41-48, 2001.

SHEPHERD, G.J. FITOPAC versão 2.0. Campinas: UNICAMP, 1996.

SNEATH, P.H.A.; SOKAL, R.R. Numerical taxonomy: principles and practice of numerical classification. San Francisco: Freeman, 1973. 573p.

STUART, S.N.; CHANSON, J.S.; COX, N.; YOUNG, B.E.; RODRIGUES, A.S.L.; FISCHMAN, D.L.; WALLER, R.W. Response to comment on "Status and trends of amphibian declines and extinctions worldwide”. Science, v.309, p.1999c, 2005.

TABANEZ, M.F.; DURIGAN, G.; KEUROGHLIAN, A.; BARBOSA, A.F.; FREITAS, C.A.; SILVA, C.E.F.; SILVA, D.A.; EATON, D.P.; BRISOLLA, G.; FARIA, H.H.; MATTOS, I.F.A.; LOBO, I.M.T.; BARBOSA, M.R.; ROSSI, M.; SOUZA, M.G.; MACHADO, R.B.; PFEIFER, R.M.; RAMOS, V.S.; ANDRADE, W.J.; CONTIERI, W.A. Plano de manejo da Estação Ecológica dos Caetetus. São Paulo: Instituto Florestal, 2005. 103p. (Série Registros, 29).
THIBAUDEAU, G.; ALTIG, R. Endotrophic anurans - development and evolution. In: MCDIARMID, R.W.; ALTIG, R. (Ed.). Tadpoles: the biology of anuran larvae. Chicago: University of Chicago Press, 1999. p.170-188.

TOLEDO, L.F.; ZINA, J.; HADDAD, C.F.B. Distribuição espacial e temporal de uma comunidade de anfíbios anuros do município de Rio Claro, São Paulo, Brasil. Holos Enviroment, v.3, p.36149, 2003.

TOLEDO, L.F.; HADDAD, C.F.B; CARNAVAL, A.C.O.Q.; BRITO, F.B. A Brazilian anuran (Hylodes magalhaesi: Leptodactylidae) infected by Batrachochytrium dendrobatidis: a conservation concern. Amphibian and Reptile Conservation, v.4, p.1721, 2006.

VERDADE, V.K.; RODRIGUES, M.T. Description of a new species of Cycloramphus (Anura, Leptodactylidae) from Atlantic Forest, Brazil. Herpetologica, v.59, p.513-518, 2003.

WEYGOLDT, P. Changes in the composition of mountain stream frog communities in the Atlantic Mountains of Brazil: frogs as indicators of environmental deteriorations? Studies on Neotropical Fauna and Environment, v.243, p.249-255, 1989.

WOLDA, H. Similarity indices, sample size and diversity. Oecologia, v.50, p.296-302, 1981.

WHITMORE, T.C. An introduction to tropical rain forests. Oxford: Clarendon Press, 1990. 238p.

ZAR, J.H. Biostatistical analysis. Upper Saddle River: Prentice Hall, 1999. 662p.

Received November 10, 2006

Accepted May 03, 2007 